\title{
Finding a New Way to Increase Project Management Efficiency in Terms of Time Reduction
}

\section{Seweryn Spalek}

\author{
Silesian University of Technology \\ Gliwice, Poland \\ E-mail.spalek@polsl.pl
}

cross $^{\text {ref }} \underline{\text { http://dx.doi.org/10.5755/j01.ee.25.5.8419 }}$

\begin{abstract}
There are three basic constraints called 'the golden triangle' in each project: time, budget and scope. Researchers and practitioners are trying to find a way to increase the efficacy of the project's outcomes in terms of shortening the project's duration, lowering budgetary costs and meeting the scope. Although several publications have been written on that topic, there is still no common solution in place. However, more in-depth research related to the specific type of projects or industries is being conducted and this paper seeks to incorporate additional knowledge into that contemporary field. Furthermore, this is of growing importance in modern, turbulent times, where the expectations of profiting from lessons learned are ever increasing.

Following the current market demands, in the article a new, innovative approach is proposed to manage the expectation that future projects will have a shorter duration. Therefore, the idea of creating specific roadmaps is proposed, which should help the decision makers improve the efficacy of project management in the company, where the process of such improvement is measured using the maturity levels assessment concept.

Based on the world-wide quantitative studies in the construction, information technology and machinery industries, specific roadmaps for each industry were determined. The purpose of these roadmaps is to indicate the most effective investment sequence in the increase of project management maturity, which should result in a decrease of future projects' duration. Moreover, discussions on the limitations of such investments are examined.
\end{abstract}

Keywords: Investment, Time pressure, Company, Projects, Improvement, PM, Implementation of Strategies, Knowledge, Innovation.

\section{Introduction}

Three of the world's most recognized Latin words, "Citius, Altius, Fortius," meaning "Faster, Higher, Stronger", have been the Olympic motto since 1894. At the time: Pierre de Coubertin proposed the motto, having borrowed it from his friend Henri Didon, a Dominican priest who taught sport close to Paris (IOC, 2007, p. 5).

These three words encourage the athlete to give his or her best during competition. To better understand the motto, we can compare it with the Olympic creed: "The most important thing in life is not the triumph, but the fight; the essential thing is not to have won, but to have fought well." Together, the Olympic motto and the creed represent an ideal that Coubertin believed in and promoted as an important life lesson that could be gained from participation in sport and the Olympic Games: that giving one's best and striving for personal excellence was a worthwhile goal. It is a lesson that can still be applied equally today, not just to athletes but to each one of us (IOC, 2007, p. 5).

Modern project management has its roots (Lenfle and Loch, 2010, p. 33) in the atomic bomb Manhattan project (Morris, 1994, p. 18) and the ballistic missile projects, Atlas and Polaris (Kerzner, 2013). The term "modern project management" is used by some authors and relates mostly to the project management approach started in the 1950s and continuing through today (Chen et al., 2011; Hill, 2004; Lenfle \& Loch, 2010; Shenhar, 2001).
Remarkably, from the very beginning of contemporary project management, projects were, and continue to be, under similar time pressure (Campos Silva et al., 2012; Chen et al., 2012; Griffin, 1993, 1997; Herroelen \& Leus, 2005; Omorede et al., 2013; Radziszewska-Zielina, 2010; Zavadskas et al., 2010). Kach and colleagues (2012, p. 377) state: The speed of technological change and shortened product life cycles have made the time-to-market requirements for developing new products increasingly stringent (Kessler and Chakrabarti, Langerak et al., 2010; Heightened competitive forces have motivated many firms to move their new products through the design and manufacturing pipeline at a faster rate, encouraging greater focus on accelerated development and compressed time lines (Prasnikar \& Skerlj, 2006; Wright et al., 1995).

The above statement for NPD (new product development) projects can be applied to most projects, whatever their nature. In our current, turbulent times, the pressure of time seems to increase to an ever greater extent. Project managers and their teams experience similar pressure to athletes: to beat the record and to go faster and faster. The first word, "Citius", of the Olympic hendiatris $^{1}$ seems to dominate projects managed by

\footnotetext{
1 Hendiatris is a figure of speech in which three words are used to emphasize one idea, for example, Wine, women, and song. Hendiatris is often used to create mottos for organizations; for example, The motto at West Point is "Duty, Honor, Country." see K. Wilson and J. Wauson, the AMA handbook of business writing: the ultimate guide to style, grammar,
} 
companies today. The majority of project stakeholders (executives, sponsors, clients, managers) expect new projects to be completed faster than ever.

Moreover, companies are always careful about spending money. Therefore, they also want to know where to invest their typically limited funds. This issue also arises when deciding where to invest to shorten the time of future projects.

This paper gives new insight into the dilemma of where and when to invest limited company funds to achieve the best approach to time reduction of future projects.

\section{(R)evolution in Managing Projects}

Project management has evolved throughout history. This evolution has occurred mostly due to the tools and techniques applied to single projects and the gradual improvement of human resource management (Avots, 1969). This situation lasted until the 1990s, when the number of projects executed by companies increased. Moreover, companies' operating environments became turbulent (Keil \& Mahring, 2010). Furthermore, the influence of project outcomes on the success of an entire company increased (Baron \& Hannan, 2002). As a result, companies placed a greater emphasis on project management. To speed up time-to-market, companies experienced increased pressure to reduce the duration of projects. The existing methods for reducing the time of ongoing single projects (e.g., application of modern scheduling techniques supported by computer technology) (Brucker et al., 1999; Iacovou \& Dexter, 2004) are significant; however, they are no longer sufficient. A new, more efficient and revolutionary approach to managing companies' portfolios of projects was needed (Cooper et al., 1999). This need generated new approaches for how to better manage projects to face the new challenges appearing in multi-project (Hofman, 2014), dynamic environments (Spalek, 2013). Accordingly, new concepts in project management were introduced, focusing on project environment and knowledge management (del Cano and de la Cruz, 2002; Ethiraj et al., 2005; Neverauskas and Stankevicius, 2008; Pemsel \& Wiewiora, 2013). Among these concepts is the idea of assessing the maturity level of project management in the company (Cooke-Davies, 2007; Fraser et al., 2003; Spalek, 2014; Tan et al., 2011).

\section{Assessing Maturity: the Purpose}

To gain competitive advantage in executing projects, companies wanted to know how well they manage projects while taking into consideration different aspects influencing the effective execution of projects (Kerzner, 2013; Rudzianskaite-Kvaraciejiene et al., 2010). The assessment outcomes should note the areas for potential improvement (Ahmad et al., 2013).

This expectation can be fulfilled by project management maturity assessment. There are several existing models of maturity assessment; however, their main purpose remains the same: to identify weak and

usage, punctuation, construction, and formatting (New York: American Management Association, 2010, p. 216). strong areas in an organization (Belt et al., 2009). By knowing its strengths and weaknesses, a company can undertake actions to improve activities related to the management of projects, resulting in an increased maturity level and improved project outcomes.

The majority of existing models assess project management maturity level on a scale from 1 to 5 , where 1 represents the lowest and 5 the highest level (Khoshgoftar \& Osman, 2009). The assessment is performed in different areas related to project management. Therefore, the assessment results in a matrix with maturity scores and testing areas (Spalek, 2011).

\section{Increasing Maturity: the Investment in the Future}

It is critical to understand that an increase of maturity level will mostly benefit future projects. Increasing by one maturity level up also has some impact, however limited, on existing projects. Because the planning phase in each project is crucial (Wyrozebski \& Spalek, 2014), the biggest possible improvements are associated with future projects. There is even a well-known quotation saying"

"Show me how your project starts and I can tell you how it will end."

If the level of maturity is increased, e.g., from level 1 to 2 , the outcomes of that action will be beneficial in new projects. For existing projects, it will usually be too late to have an impact.

Therefore, the decision to assess and then increase the project management maturity level in a company is an investment in future projects.

Investment "in maturity" is time consuming and money intensive; therefore, to achieve the highest possible time reduction of future projects, it is crucial to decide where and when (in which sequence) a company investment should be placed. Moreover, a company's investment funds are often very limited, making the issue even more important. Therefore, it is essential for companies today to have a road map guiding decision makers on the following topic:

"In which areas and in what sequence should limited funds be most effectively invested in my company?".

\section{The Research Method}

The prediction of the future is a complex issue (Glenn \& Gordon, 2003), often involving various methods and techniques, and thus has a wide record in publications.(Booth, 2006; Galbraith \& Merrill, 1996; Lacher et al., 1995; Landeta, 2006; Onkal et al., 2013).

To predict reduction of the future time of projects, questionnaire-based cross-impact analysis was used following the ideas presented by Fabiana Scapolo and Ian Miles (2006, p. 680-681). The method included the following steps:

- choosing the object of studies;

- $\quad$ selection of subject to study;

- choosing the experts to participate;

- gathering the data using questionnaires;

- data analysis and conclusions.

\footnotetext{
${ }^{2}$ Author unknown, also exists as: "Show me how your project starts and I can tell you how it will finish" or "Show me how your project starts and I show you how it will end".
} 


\section{Three Industries: Construction, Information Technology and Machinery}

The research presented in this article was part of a larger effort supported by the National Science Centre, focusing on world-wide studies of maturity in project management in the chosen industries. The overall research was designed in two major steps.

The first step was to conduct quantitative empirical studies on project management maturity levels in three types of industries: machinery, construction and information technology. Data from 447 global companies, mostly medium- and large-sized ones, was collected. Ninety-eight per cent of them earned over $€ 2,000,000$ per year, and 99,5 $\%$ of them employed over 49 people.

The second step, which is discussed in this study, was designed to investigate the relationship between the increase in maturity level in project management and the predicted duration of forthcoming projects.

\section{The Assessment}

For the purpose of this study, a model was used that assesses the company's project management maturity in four areas (Spalek, 2011):

- methods (M) (Gary et al., 2011; Ji \& Sedano, 2011);

- human resources (HR) (Levin, 2010; McDonough, 2000);

- project environment (E) (Elbanna, 2013; Killen \& Kjaer, 2012);

- knowledge management (KM) (Basu, 2014; Gasik, 2011).

The description of the maturity assessment areas is shown in table 1 .

Project Management Maturity Assessment Areas

\begin{tabular}{lll}
\hline \multicolumn{1}{c}{ ID } & \multicolumn{1}{c}{ Area } & \multicolumn{1}{c}{ Description } \\
\hline 1. & Human Resources & staffing, career paths, motivation, training, team work \\
2. & $\begin{array}{l}\text { Methods (incl. Tools \& } \\
\text { methods, tools, techniques and means used for project planning and execution; risk, requirements, scope, costs, time } \\
\text { and quality management }\end{array}$ \\
3. & Environment & organizational structures, top management support, stakeholders' management, company culture \\
4. & Knowledge Management & lessons learned approach, gathering data and experience for on-going operations and future references \\
\hline
\end{tabular}

In the applied project management maturity model the results of the assessment are reported from level 1 to 5:

- LEVEL 1: Initial;

- LEVEL 2: Standardized;

- LEVEL 3: Appliance;

- LEVEL 4: System Management;

- LEVEL 5: Self-improvement.

The experts were asked to express their opinion on an increase of maturity level by one increment (from 1 to 2 , from 2 to 3 , etc.) and how it influences the time reduction of future projects in their companies. The possible impact was measured on a scale from 1 to 5 , as shown in table 2 . The assessment was made separately in each testing area.

The Impact on Time Reduction on Future Projects

Table 2

\begin{tabular}{cc}
\hline Impact Level & Description \\
\hline $\mathbf{1}$ & No influence \\
$\mathbf{2}$ & $1-10 \%$ \\
$\mathbf{3}$ & $11-20 \%$ \\
$\mathbf{4}$ & $21-30 \%$ \\
$\mathbf{5}$ & over $30 \%$ \\
\hline
\end{tabular}

In our study, the experts were practitioners from the investigated companies. The invitation to participate in this study was sent to 308 chosen experts as a follow-up to the major global study on project management maturity. The experts were chosen based on the demographic information obtained in the first step of the overall research. They were experienced managers that had at least five years of experience and possessed a deep knowledge of the projects executed in their companies. Moreover, the invitations were sent to experts from companies that reported a maturity level of at least 2 in each of the testing areas.

The response rate was $63 \%$. Such a high rate was obtained as there were individually approached named persons who expressed, in the first step of overall research, their willingness to participate in the second step of the studies. Non-response bias was tested by comparing the demographic data of participating and non-participating experts. No significant difference was found, proving that survey respondents represent the overall sample accurately.

\section{Results and Discussion}

Data from 39 information technology, 48 construction and 107 machinery industry global companies was collected. The reliability of data was checked using Cronbach's alpha, resulting in a value of over 0,9 in each testing area.

Data analysis using mean, median and mode values was performed. The equality of variances was tested using Levene's test and the equality of means using a t-test, and satisfactory results were obtained as the significance for Levene's test was greater than 0,05 . Additionally, Spearman's rho correlation coefficients and factor analysis using rotated component matrix were calculated for further rigid data analyses. The data analysis was performed using Statistical Package for the Social Sciences (IBM SPSS build V21.0.0).

The results revealed differences in the predicted impact of change in maturity level on the duration of future projects. This level of impact depended on the specific change in the designated area of assessment (e.g., a change from level 1 to 2 in the knowledge management area) and varied between industries.

\section{The Impact on Future Projects: by Maturity Area and Type of Industry}

The data analysis revealed that the dispersion of the acquired data is low; consequently, the mean value was chosen to explain the results. Using the mean value allows 
the results to be presented more clearly, without going into deep statistical details and allows the development of a full, more comprehensive picture. The mean values of impact on the future projects are shown in table 3.
The Impact on Future Projects by Industry (CONS, IND, IT) and Change of Maturity Level in the Areas of Methods (M), Human Resources (HR), Project Environment (E) and Knowledge Management (KM).

Table 3

Statistics (Mean Value of Impact on Future Projects)

\begin{tabular}{|c|c|c|c|c|c|c|c|c|c|c|c|c|c|c|c|c|}
\hline & $\begin{array}{c}\mathrm{M} \\
1-2\end{array}$ & $\begin{array}{c}\mathrm{M} \\
2-3\end{array}$ & $\begin{array}{c}\mathrm{M} \\
3-4\end{array}$ & $\begin{array}{c}\mathrm{M} \\
4-5\end{array}$ & $\begin{array}{l}\text { HR } \\
1-2\end{array}$ & $\begin{array}{l}\text { HR } \\
2-3\end{array}$ & $\begin{array}{l}\text { HR } \\
3-4\end{array}$ & $\begin{array}{l}\mathrm{HR} \\
4-5\end{array}$ & $\begin{array}{c}\mathrm{E} \\
1-2\end{array}$ & $\begin{array}{c}\mathrm{E} \\
2-3\end{array}$ & $\begin{array}{c}E \\
3-4\end{array}$ & $\begin{array}{c}\mathrm{E} \\
4-5\end{array}$ & $\begin{array}{l}\mathrm{KM} \\
1-2\end{array}$ & $\begin{array}{l}\mathrm{KM} \\
2-3\end{array}$ & $\begin{array}{l}\mathrm{KM} \\
3-4\end{array}$ & $\begin{array}{l}\mathrm{KM} \\
4-5\end{array}$ \\
\hline CONS & 3,96 & 3,96 & 3,21 & 2,46 & 3,96 & 3,96 & 3,21 & 2,46 & 3,21 & 3,21 & 2,46 & 1,71 & 3,21 & 3,21 & 2,46 & 1,71 \\
\hline IND & 3,88 & 3,88 & 3,16 & 2,44 & 3,88 & 3,88 & 3,16 & 2,44 & 3,16 & 3,16 & 2,44 & 1,72 & 3,16 & 3,16 & 2,44 & 1,72 \\
\hline IT & 3,90 & 3,90 & 3,15 & 2,41 & 3,90 & 3,90 & 3,15 & 2,41 & 3,87 & 3,87 & 3,13 & 2,38 & 3,87 & 3,87 & 3,13 & 2,38 \\
\hline
\end{tabular}

The impact on future projects depends on the type of industry. The highest impact levels $(3,96)$ were observed for the change from level 1 to 2 and from 2 to 3 in the methods (M) and human resources (HR) areas in the construction industry (CONS). The lowest impact (1.71) also appeared in the construction industry; however, it was observed in the areas of environment (E) and knowledge management (KM) for the change of maturity from level 4 to 5. Note, in each type of the studied industries, the potential impact on future projects is the highest if the company is at the initial (1) or standardized (2) level of maturity in project management and wants to increase it by going one level up. This observation is true for each assessment area: methods, human resources, environment and knowledge management.

When a company reports already having appliance (3) or system management (4), maturity levels and wants to increase it by one level, the impact on future projects' duration subsequently decreases. However, this reduction is greater in the construction and machinery industries than in information technology companies. Therefore, which project management maturity area the company should first invest funds in to reduce the future project's duration depends on the type of industry. Moreover, the investment sequence depends on the current level of maturity in the company in each testing area, meaning that for a chosen industry, one should consider a different roadmap, showing where and in which sequence the investment in project management maturity should be placed.

\section{Different Industries, Different Approach?}

This study on the influence of the increase of project management maturity on future projects' time reduction was focused on three types of industries:

- Construction, one of the "world present" sectors that has projects that are, to some extent, inherited in its long history. The projects associated with these sectors are described and considered by numerous authors (Davies et al., 2009; Dominguez et al., 2009).

- Information Technology (IT), the companies of which are admittedly spread throughout the globe. The IT projects are described and discussed for many different types, such as agile (Thomke and Reinertsen, 1998) or Internet projects (Mahadevan, 2000).

- The machinery industry, which operates in the background of the above two industries as well as many others, is present in many countries and is a backbone industry for the other sectors. Therefore, its importance for the global economy is very high. However, a limited amount of research in this particular sector can be found in the literature. The examples are mostly qualitative case studies describing new product development (NPD) practices (Ahmad et al., 2013; Huang et al., 2004; Matsui et al., 2008), which are crucial for machinery industry companies.

\section{The Investment Road Map: The Idea}

Based on the factor analysis (as shown in Table 4), a road map is proposed showing the investment path in maturity areas, which should result in the biggest pay-offs in reduction of time in future projects. Analysing the groups of factors in the table, the proposed roadmaps for the companies was built. This road map operates in the areas of methods and techniques (M), human resources $(\mathrm{HR})$, project environment (E) and project knowledge management (KM), as well as the associated change in level of maturity (e.g., from 2 to 3 ), which is noted, for example, as follows: M 2-3 (the change in maturity from level 2 to 3 in the area of methods and techniques).

In general, note that at the beginning of the road map, the investment has the biggest impact on the duration of future projects and subsequently decreases along the way.

Factor Analysis

Table 4

Rotated Component Matrix ${ }^{\mathrm{a}, \mathrm{b}}$

\begin{tabular}{lrcr}
\hline \hline & \multicolumn{3}{c}{ Component } \\
\hline & 1 & 2 & 3 \\
\hline M2-3 &, 964 &, 245 &,- 088 \\
HR1-2 &, 964 &, 245 &,- 088 \\
HR2-3 &, 964 &, 245 &,- 088 \\
M1-2 &, 964 &, 245 &,- 088 \\
HR3-4 &, 953 &, 265 &, 146 \\
E1-2 &, 953 &, 265 &, 146 \\
KM2-3 &, 953 &, 265 &, 146 \\
KM1-2 &, 953 &, 265 &, 146 \\
E2-3 &, 953 &, 265 &, 146 \\
M3-4 &, 953 &, 265 &, 146 \\
M4-5 &, 719 &, 253 &, 648 \\
HR4-5 &, 719 &, 253 &, 648 \\
E3-4 &, 719 &, 253 &, 648 \\
KM3-4 &, 719 &, 253 &, 648 \\
KM4-5 &,- 019 &, 093 &, 992 \\
E4-5 &,- 019 &, 093 &, 992 \\
\hline Extraction Method: Principal Component Analysis. \\
Rotation Method: Varimax with Kaiser Normalization. \\
a. BRANCH=CONS; b. Rotation converged in 18 iterations \\
\multicolumn{4}{c}{ Rotated Component Matrix } \\
\hline \hline
\end{tabular}




\begin{tabular}{lrrr}
\hline \multicolumn{4}{c}{ Rotated Component Matrix $^{\mathbf{a}, \mathbf{b}}$} \\
Component
\end{tabular}

\begin{tabular}{lccc}
\hline \hline & \multicolumn{3}{c}{ Component } \\
\hline & 1 & 2 & 3 \\
\hline HR1-2 &, 947 &, 148 &, 272 \\
HR2-3 &, 947 &, 148 &, 272 \\
M1-2 &, 947 &, 148 &, 272 \\
M2-3 &, 947 &, 148 &, 272 \\
KM2-3 &, 934 &, 190 &, 297 \\
E2-3 &, 934 &, 190 &, 297 \\
E1-2 &, 934 &, 190 &, 297 \\
KM1-2 &, 934 &, 190 &, 297 \\
HR3-4 &, 817 &, 227 &, 519 \\
M3-4 &, 817 &, 227 &, 519 \\
E3-4 &, 783 &, 284 &, 543 \\
KM3-4 &, 783 &, 284 &, 543 \\
HR4-5 &, 288 &, 327 &, 891 \\
M4-5 &, 288 &, 327 &, 891 \\
E4-5 &, 254 &, 387 &, 872 \\
KM4-5 &, 254 &, 387 &, 872 \\
\hline Extraction Method: Principal Component Analysis. \\
Rotation Method: Varimax with Kaiser Normalization. \\
a. BRANCH=IT; b. Rotation converged in 9 iterations. \\
\end{tabular}

The Investment Road Map: Construction Industry

The construction sector is one of the largest industries traditionally associated with using project management. The proposed road map revealed that the biggest pay-off is associated with an increase of maturity level from 1 to 2 and from 2 to 3 in the methods (M 1-2, M 2-3) and human resources areas (HR 1-2, HR 2-3).

The road map can be described in the following four steps:

Step One

Assuming that the company is at an initial (1) maturity level in all areas, the first step in investment should be an increase of maturity in the methods (M) and human resources areas (HR) until they reach the level 3.

Step Two

Then, in the second step, the investment should be placed in gradually reaching level 3 in the environment and knowledge management areas (E 1-2, E 2-3, KM 1-2, KM 2-3), and the increase in methods and human resources should continually increase until they reach level 4 (HR 3-4, M 3-4).

Step Three

The third step should include activities improving the maturity in the environment and knowledge management areas until they report level 4 (E 3-4, KM 3-4) and the methods and human resources areas until level 5 (M 4-5, HR 4-5).

Step Four

Finally, in the fourth step, the increase should be from level 4 to 5 in the environment and knowledge management areas (E 4-5, KM 4-5).

Figure 1 shows the investment road map for the construction industry.

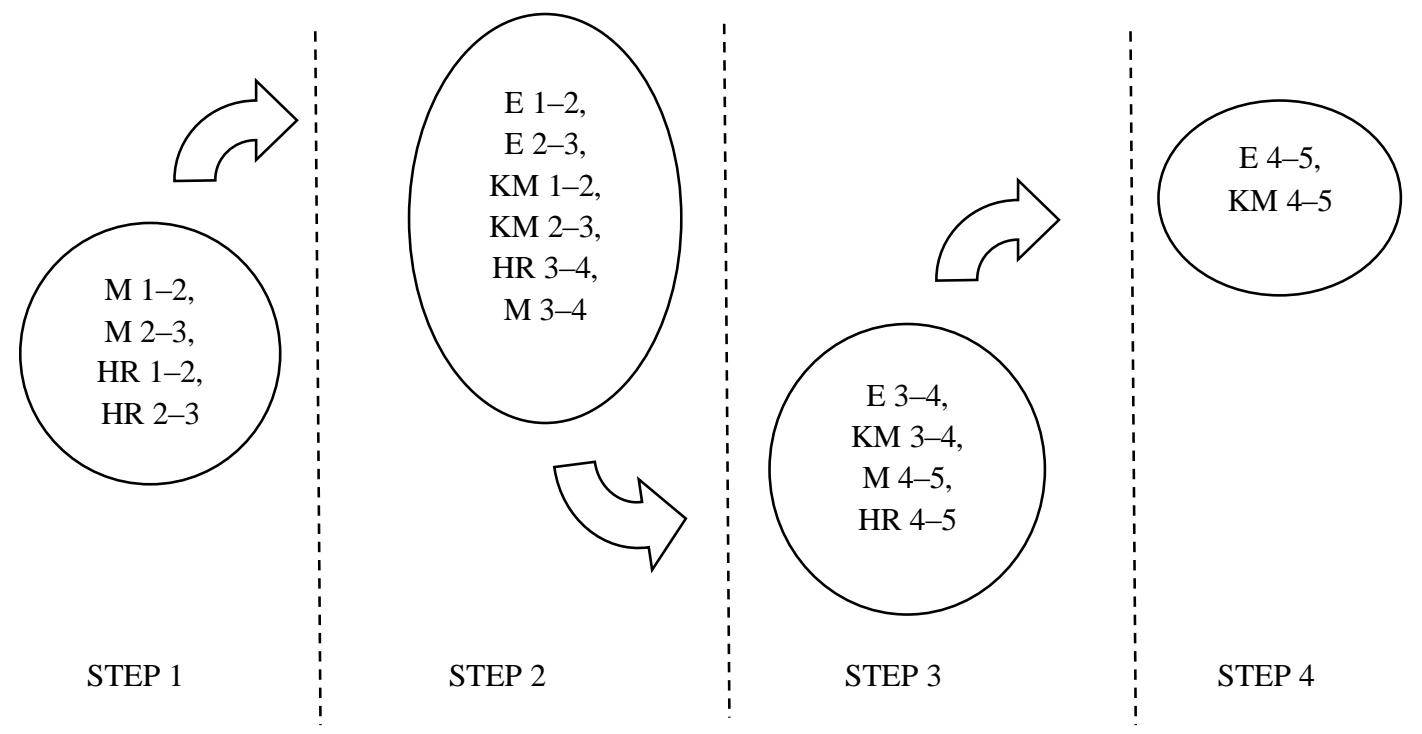

Figure 1. Investment road map for the construction industry 
Comparing Steps in Construction Companies: the Reduction of Impact

Remarkably, if assuming that in the first step, the impact on reduction of time of future projects is 100 , then in the second step, it equals 81; in the third, 62; and in the fourth, 43.

This information is useful for investments in a specific company, as companies in the same industry differ from one another. After performing the first step, the total investment and detailed impact on a project's duration can be measured. Then, knowing the predicted reduction of impact, one can estimate the possible outcomes in the second step toward the investment effort and decide if it is worth it to proceed. The same approach can be performed before step three and four. Following this advice means, of course, that time gaps are needed between successive steps to reassess the situation.

\section{The Investment Road Map: Information Technology}

After construction, the second industry traditionally associated with the project management sector is information technology (IT). Moreover, both industries report a long project management application history.

The investment road map for information technology consists of six steps.

Step One

In step one, the investment in increasing project management maturity levels should be performed to go from level 1 to 2 and from 2 to 3 in the methods and human resources areas (M 1-2, M 2-3, HR 1-2, HR 2-3).

Step Two

After the first investments, the company should consider investments to increase the level of maturity from 1 to 2 and then from 2 to 3 in the remaining two areas: environment and knowledge management (E 1-2, E 2-3, KM 1-2, KM 2-3).

\section{Step Three}

In the third step, the project management maturity level should be increased from 3 to 4 in the methods and human resources areas (M 3-4, HR 3-4).

Step Four

In this step, as in step three, one goes up from level 3 to 4 in the environment and knowledge management areas (E 3-4, KM 3-4).

Step Five

The fifth step is designated for improvement in the methods and human resources areas from level 4 to 5 (M 4 5, HR 4-5).

Step Six

In the last step, the investment should be placed to increase the maturity level from 4 to 5 in the areas of environment and knowledge management (E 4-5, KM 4-5).

Figure 2 shows the investment road map for information technology companies.

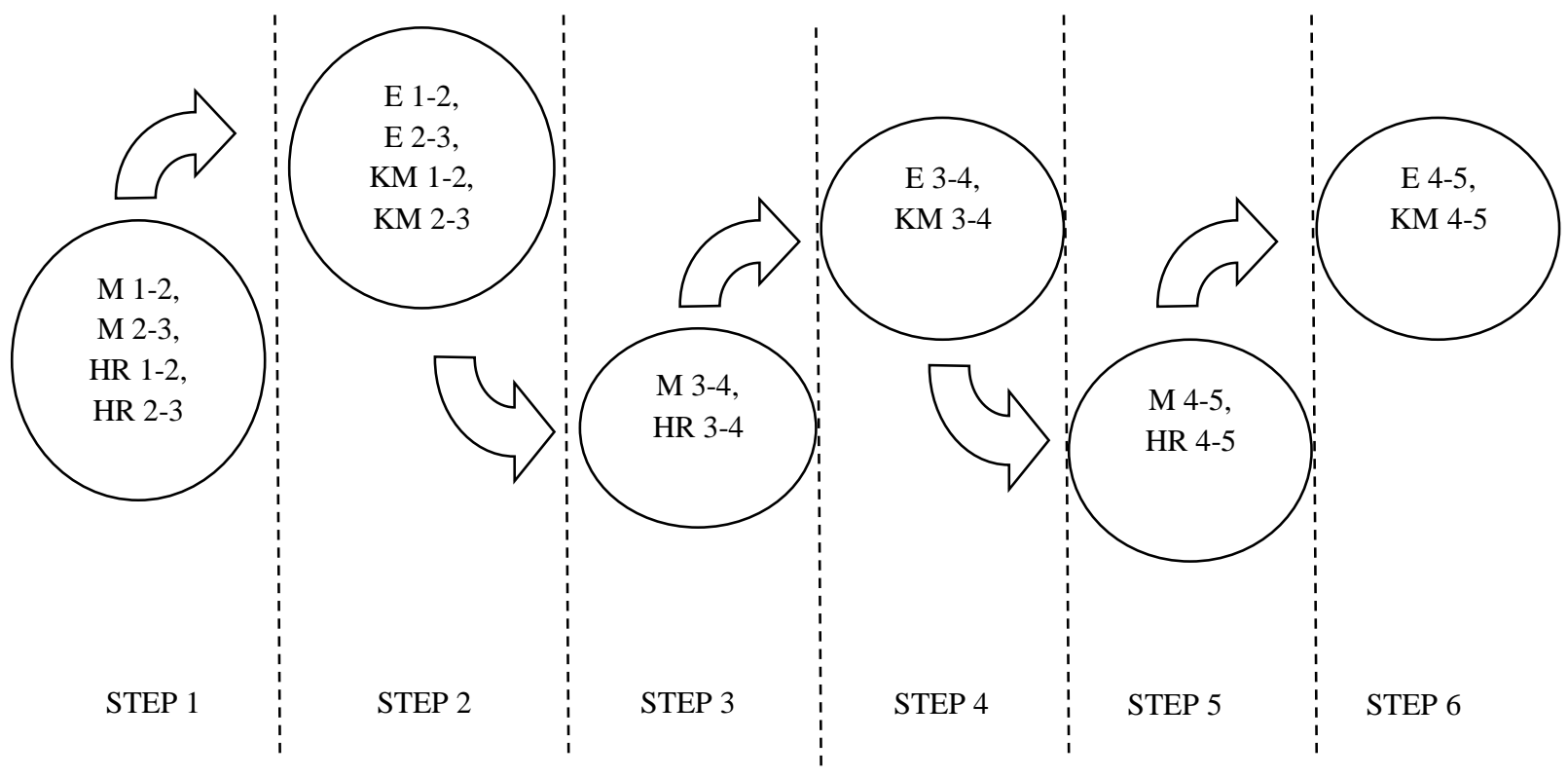

Figure 2. Investment road map for information technology companies

Comparing Steps in IT Companies: The Reduction of Impact

The highest potential impact on future projects in the IT industry occurs when investing in the areas indicated in the first step and then gradually decreases.

Assuming that the impact in the first step equals 100, the impact on future projects' duration of investment in step two is 99. Accordingly, in step three, the duration is 81 ; in step four, 80 ; in step five, 62 ; and, finally, in step six, 61 .
Despite a relatively greater number of steps in comparison to the construction industry, the differences between some pairs of steps ( 1 and 2, 3 and 4, 5 and 6) are small. Thus, the decision to continue the investment after each step is of a different nature than in the construction industry where differences are bigger.

\section{The Investment Road Map: Machinery Industry}

The products of the machinery industry are the machines, tools, parts and devices used by the other industries. This industry, like construction and IT, also has a wide representation among companies world-wide. 
However, a limited amount of project management related research exists for this sector.

The investment in project management maturity in the machinery industry should be considered in the following four steps:

Step One

In the first step, the investment in an increase of maturity levels from 1 to 2 and, successively, from 2 to 3 should be considered in the areas of methods and human resources (M 1-2, M 2-3, HR 1-2, HR 2-3).

Step Two

The next investments should be focused on further increases in the methods and human resources areas up to level 4 and, in parallel, they should be focused on further increases in the areas of environment and knowledge management from levels 1 to 3 (M 3-4, HR 3-4, E 1-2, E 2-3, KM 1-2, KM 2-3).

\section{Step Three}

In step three, an increase of project management maturity up to level 4 is advised in the environment and knowledge management areas (E 3-4, KM 3-4). Additionally, investment in the methods and human areas is suggested until they reach level 5 (M 4-5, HR 4-5).

\section{Step Four}

This final step is dedicated to the environment and knowledge management areas to reach a level 5 of project management maturity (E 4-5, KM 4-5).

Figure 3 shows the investment road map for the machinery industry.

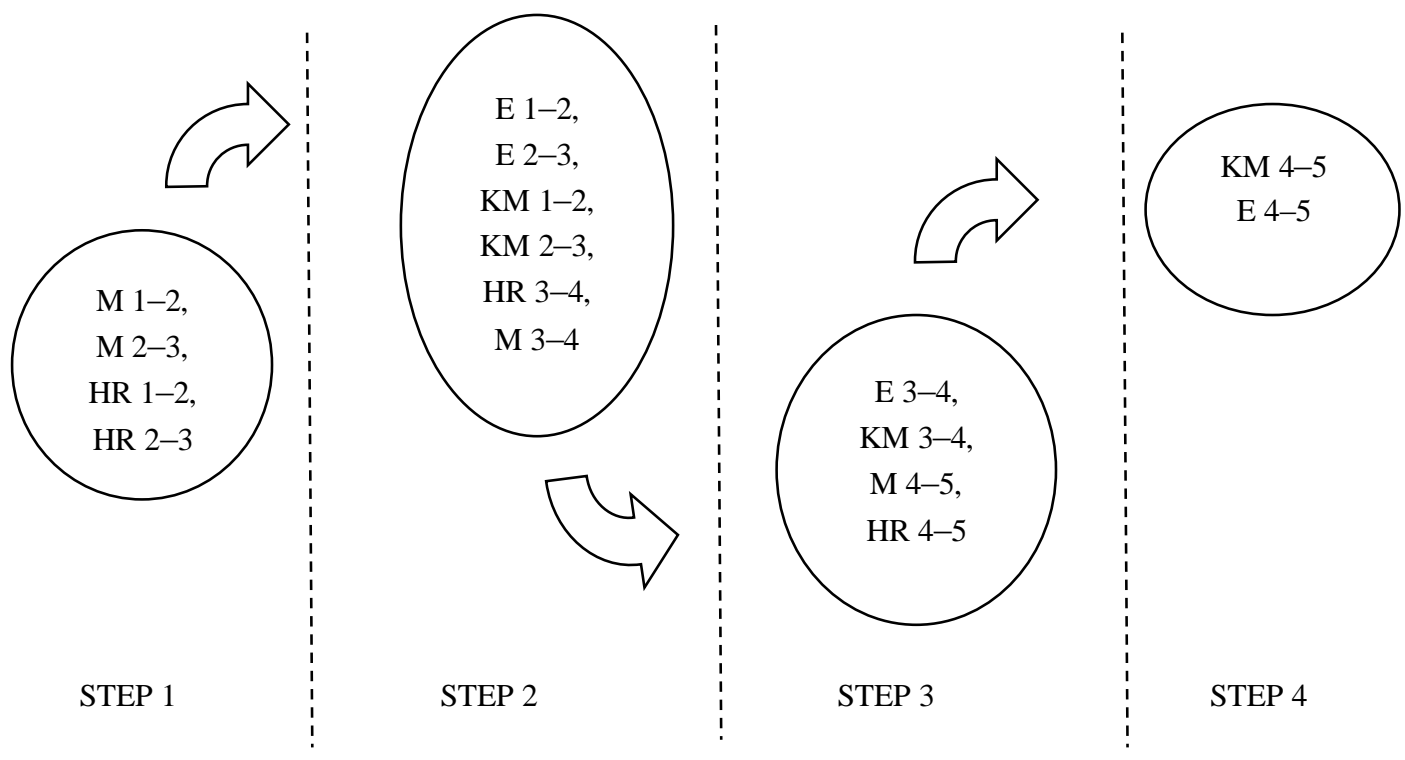

Figure 3. Investment road map for the machinery industry

Comparing Steps in Machinery Industry Companies: the Reduction of Impact

If one assumes that the possible impact on future project time reduction in the machinery industry equals 100 as a result of performing step 1, the execution of step 2 will thus result in an impact level of 81 . For steps 3 and 4, there is a further reduction of impact to 64 and 44, respectively.

After performing each step and comparing the effort undertaken to the reported project outcomes, this information can be used to decide whether to continue with further investments in increasing maturity levels.

\section{Conclusions}

\section{The Traditional vs. Agile Approach to Managing Projects}

The outcomes for the construction and machinery industries are alike, whereas the results of the study in information technology companies differs. This could be the result of similarities between the type of projects undertaken by both the construction and machinery industry and the different projects undertaken by IT companies. The construction and machinery industry companies execute projects in a more traditional approach, whereas IT projects have a greater tendency to migrate toward agility in project management. The concepts of traditional vs. agile approach in project management are widely discussed by (Fernandez \& Fernandez, 2008; Shenhar \& Dvir, 1996). That contrast would explain the major differences between the proposed investment roadmaps that are associated with either a more traditional or agile approach to project management.

Construction and Machinery: the Traditional Approach

In the traditional approach, the general advice is to invest gradually in all four areas of maturity with some advance investment in project management standards, tools and techniques and in the competencies of people involved in projects. The investment in company structures supporting project execution or project knowledge management areas should be considered in direct relation to progress in the methods and human resources areas.

Information Technology: The Agile Approach

Agility, as defined by its founders ${ }^{3}$, is less focused on strict methods and tools and more on knowledge flow, creating an appropriate working environment and team building processes (Dingsoyr et al., 2012). Therefore,

\footnotetext{
3 see: http://agilemanifesto.org/; accessed November 2013.
} 
explaining why the investment in that type of project should be performed gradually and in parallel in each of the following areas: methods, human resources, environment and knowledge management.

Although this study is limited to three industries, the suggested roadmaps can be used by other industries as well, especially by a wide range of manufacturing companies (NAICS, 2012). A company can choose a road map by assessing the similarities of the projects being executed to construction and machinery or IT projects. However, for some sectors, such as healthcare (Adler et al., 2003) or education (Palacios-Marques et al., 2013), more studies are needed to develop their specific road maps systems.

\section{Continuous Improvement? Not Necessary!}

The majority of academics and practitioners think that continuous improvement is vital for a company's operations and its survival in the turbulent market. This approach is also a noticeable concept of increasing project management maturity levels as a continuous process, which should result in reaching the highest maturity level in all assessment areas.

However, based on existing studies of maturity (Becker et al., 2009; Grant \& Pennypacker, 2006; Mullaly \&Thomas, 2010; Pasian, 2011; Rohrbeck, 2010), the vast majority of companies today report, on average, the second or third level of maturity in different industries and assessment areas. Therefore, more effort is put into discussing how the company should proceed with maturity improvement to achieve "the top." However, some doubts exist if "the top" is even obtainable as there is a risk that assessment criteria can be changed over time as project management develops further. The first signs of such an approach are described in the model proposed by PMI (2008), in which no levels of maturity are defined. Instead, maturity is measured using a best practices list, which is continuously expanded by the PMI. This approach results in a "never ending" continuous effort to increase project management maturity in the company.

Continuous improvement, however appropriate in theory, cannot always be the best solution for a company. As our study revealed, the impact of the increase of maturity on the reduction of future projects decreases over subsequent levels of maturity. The biggest impact occurs at the very beginning when a company is making its first steps on the road map. Then, the impact decreases by more than $50 \%$ in the traditional approach to project management (represented by construction and machinery industries) and by approximately $40 \%$ in the agile approach (represented by information technology companies). This brings into the question whether continuous improvement in maturity is effective for the company in terms of invested funds and achieved outcomes.

Therefore, there should be time breaks in between steps on the investment road map to measure, ex post ${ }^{4}$, the

\footnotetext{
${ }^{4}$ The translation from Latin means "after the fact". The use of historical returns has traditionally been the most common way to predict the probability of incurring a loss on any given day. Ex-post is the opposite of
}

real impact of the increase in project management maturity on the recorded project's time reduction.

Based on this study, one knows the size of the predicted decrease of impact in the next step for traditional and agile projects. Therefore, one can compare possible benefits with the estimated effort needed to continue with the next step on the road map. As a result, one can conclude that the investment in further progress in project management maturity does not pay off and the limited company's investment funds can be spent on other more promising and vital company activities.

\section{Limitations and Future Directions}

The research is limited to three types of industries, represented by 194 organisations with 107 belonging to machinery, 48 to construction and 19 to IT companies. In quantitative analysis, the size of this sample, especially of the latter two industries, can be assumed to be rather small. Therefore, definitive conclusions and generalisations supporting the outcomes of our study should await a larger sample, especially of IT and construction industries.

The method of the prediction of the costs of forthcoming projects by investigating experts' opinions is constrained by the quality of the respondents' judgment, as is the case in all surveys of experts. Generally, predicting future outcomes is an extremely difficult issue (Glenn \& Gordon, 2003). However, it was a conscious decision to use this method, despite its limitations, to advance the current stage of knowledge.

Some of the limitations of the study can be strengthened to show the directions for future research. The mainstream method would be to investigate the other industries for which projects are a vital part of their operations with the same method. Therefore, follow-up research could be dedicated to the automotive, aerospace or mining sectors.

Moreover, a study on the relationship between different investment types and an increase in maturity level would be advised. It would also be desirable for a new study to investigate the direct influence of different types of investments on projects' outcomes.

It may also be worth considering research into checking whether project management is not geographically sensitive, as the other recent studies on project management performance areas suggest.

The results of this study advance the current state of knowledge in the project management area. However, the problem of linking investments in project management to outcomes for an entire company is complex. Hence, the considerations presented in the paper provide a better understanding of this complexity in the area of project duration and could be a trigger point for further studies of other types of project outcomes.

\section{Acknowledgments}

This work was supported by the National Science Centre grant.

ex-ante, which means "before the event". Source: http://www.investopedia.com/ retrieved on November 2013. 


\section{References}

Adler, P. S., Riley, P., Kwon, S. W., Signer, J., Lee, B., \& Satrasala, R. (2003). Performance improvement capability: Keys to accelerating performance improvement in hospitals. California Management Review, 45(2). http://dx.doi.org/10.2307/41166163

Ahmad, S., Mallick, D. N., \& Schroeder, R. G. (2013). New Product Development: Impact of Project Characteristics and Development Practices on Performance. Journal of Product Innovation Management, 30(2), 331-348. http://dx.doi.org/10.1111/j.1540-5885.2012.01002.x

Avots, I. (1969). Why Does Project Management Fail. California Management Review, 12/1, 77-82. http://dx.doi.org/10.2307/41164208

Baron, J. N., \& Hannan, M. T. (2002). Organizational blueprints for success in high-tech start-ups: Lessons from the Stanford Project on emerging companies. California Management Review, 44(3). http://dx.doi.org/10.2307/41166130

Basu, R. (2014). Managing quality in projects: An empirical study. International Journal of Project Management, 32(1), 178-187. http://dx.doi.org/10.1016/j.ijproman.2013.02.003

Becker, J., Knackstedt, R., \& Poppelbuss, J. (2009). Developing Maturity Models for IT Management - A Procedure Model and its Application. Business \& Information Systems Engineering, 1(3).

Belt, P., Oiva-Kess, A., Harkonen, J., Mottonen, M., \& Kess, P. (2009). Organisational maturity and functional performance. International Journal of Management and Enterprise Development, 6(2), $147-164$. http://dx.doi.org/10.1504/IJMED.2009.022624

Booth, H. (2006). Demographic forecasting: 1980 to 2005 in review. International Journal of Forecasting, 22(3), 547581. http://dx.doi.org/10.1016/j.ijforecast.2006.04.001

Brucker, P., Drexl, A., Mohring, R., Neumann, K., \& Pesch, E. (1999). Resource-constrained project scheduling: Notation, classification, models, and methods. European Journal of Operational Research, 112(1), 3-41. http://dx.doi.org/10.1016/S0377-2217(98)00204-5

Campos Silva, D. D., Santiago, L. P., \& Silva, P. M. S. (2012). Impact of Premature Information Transfer on Cost and Development Time of Projects. IEEE Transactions on Engineering Management, 59(4), $692-704$. http://dx.doi.org/10.1109/TEM.2012.2187661

Chen, B., Liou, F. M., \& Huang, C. P. (2012). Optimal Financing Mix of Financially Non-Viable Private-Participation Investment Project with Initial Subsidy. Inzinerine Ekonomika-Engineering Economics, 23(5), 452-461.

Chen, Y. Q., Liu, J. Y., Li, B., \& Lin, B. (2011). Project delivery system selection of construction projects in China. Expert Systems with Applications, 38(5), 5456-5462. http://dx.doi.org/10.1016/j.eswa.2010.10.008

Cooke-Davies, T. (2007). Project Management Maturity Models. In P. W. G. Morris and J. K. Pinto (Eds.), Wiley Guide to Managing Projects (pp. 1234-1255). Hoboken, NJ, USA: John Wiley \& Sons. http://dx.doi.org/10. 1002/9780470172391.ch49

Cooper, R. G., Edgett, S. J., \& Kleinschmidt, E. J. (1999). New product portfolio management: Practices and performance. Journal of Product Innovation Management, 16(4), 333-351. http://dx.doi.org/10.1016/S0737-6782(99)00005-3

Davies, A., Gann, D., \& Douglas, T. (2009). Innovation in Megaprojects: Systems Integration At London Heathrow Terminal 5. California Management Review, 51(2). http://dx.doi.org/10.2307/41166482

del Cano, A., \& de la Cruz, M. P. (2002). Integrated methodology for project risk management. Journal of Construction Engineering and Management-Asce, 128(6), 473-485. http://dx.doi.org/10.1061/(ASCE)0733-9364(2002)128:6(473)

Dingsoyr, T., Nerur, S., Balijepally, V., \& Moe, N. B. (2012). A decade of agile methodologies: Towards explaining agile software development. Journal of Systems and Software, 85(6). http://dx.doi.org/10.1016/j.jss.2012.02.033

Dominguez, D., Worch, H., Markard, J., Truffer, B., \& Gujer, W. (2009). Closing the Capability Gap: Strategic Planning For The Infrastructure Sector. California Management Review, 51(2). http://dx.doi.org/10.2307/41166479

Elbanna, A. (2013). Top management support in multiple-project environments: an in-practice view. European Journal of Information Systems, 22(3), 278-294. http://dx.doi.org/10.1057/ejis.2012.16

Ethiraj, S. K., Kale, P., Krishnan, M. S., \& Singh, J. V. (2005). Where do capabilities come from and how do they matter? A study in the software services industry. Strategic Management Journal, 26(1), 25-45. http://dx.doi.org/10.1002/smj.433

Fernandez, D. J., \& Fernandez, J. D. (2008). Agile Project Management - Agilism Versus Traditional Approaches. Journal of Computer Information Systems, 49(2), 10-17.

Fraser, P., Farrukh, C., \& Gregory, M. (2003). Managing product development collaborations - a process maturity approach. Proceedings of the Institution of Mechanical Engineers Part B-Journal of Engineering Manufacture, 217(11), 1499-1519. http://dx.doi.org/10.1243/095440503771909890

Galbraith, C. S., \& Merrill, G. B. (1996). The politics of forecasting: Managing the truth. California Management Review, 38(2). http://dx.doi.org/10.2307/41165831 
Gary, K., Enquobahrie, A., Ibanez, L., Cheng, P., Yaniv, Z., Cleary, K., Kokoori, S., Muffih, B., \& Heidenreich, J. (2011). Agile methods for open source safety-critical software. Software-Practice \& Experience, 41(9). http://dx.doi.org/10.1002/spe.1075

Gasik, S. (2011). A Model of Project Knowledge Management. Project Management Journal, 42(3), $23-44$. http://dx.doi.org/10.1002/pmj.20239

Glenn, J. C., \& Gordon, T. J. (2003). Futures Research Methodology. Washington D.C.: The United Nations University.

Grant, K. P., \& Pennypacker, J. S. (2006). Project management maturity: An assessment of project management capabilities among and between selected industries. IEEE Transactions on Engineering Management, 53(1), 59-68. http://dx.doi.org/10.1109/TEM.2005.861802

Griffin, A. (1993). Metrics for Measuring Product Development Cycle Time. Journal of Product Innovation Management, 10(2), 112-125. http://dx.doi.org/10.1016/0737-6782(93)90003-9

Griffin, A. (1997). The effect of project and process characteristics on product development cycle time. Journal of Marketing Research, 34(1), 24-35. http://dx.doi.org/10.2307/3152062

Herroelen, W., \& Leus, R. (2005). Project scheduling under uncertainty: Survey and research potentials. European Journal of Operational Research, 165(2), 289-306. http://dx.doi.org/10.1016/j.ejor.2004.04.002

Hill, G. M. (2004). Evolving the project management office, a competency continuum. Information Systems Management, 21(4), 45-51. http://dx.doi.org/10.1201/1078/44705.21.4.20040901/84187.6

Hofman, M. (2014). Models of PMO functioning in a multi-project environment. Procedia - Social and Behavioral Sciences, 119, 46-54.

Huang, X. L., Soutar, G. N., \& Brown, A. (2004). Measuring new product success: an empirical investigation of Australian SMEs. Industrial Marketing Management, 33(2), 117-123. http://dx.doi.org/10.1016/S00198501(03)00034-8

Iacovou, C. L., \& Dexter, A. S. (2004). Turning around runaway information technology projects. California Management Review, 46(4). http://dx.doi.org/10.2307/41166275

IOC (2007). The Olympic symbols, 2nd ed.. The Olympic Museum: International Olympic Committee.

Ji, F., \& Sedano, T. (2011). Comparing Extreme Programming and Waterfall Project Results. IEEE.

Kach, A., Azadegan, A., \& Dooley, K. J. (2012). Analyzing the successful development of a high-novelty innovation project under a time-pressured schedule. $R \& D$ Management, 42(5), 377-400.

Keil, M., \& Mahring, M. (2010). Is Your Project Turning into a Black Hole?. California Management Review, 53(1). http://dx.doi.org/10.1525/cmr.2010.53.1.6

Kerzner, H. (2013). Project management: a systems approach to planning, scheduling, and controlling (11 ed.). Hoboken, NJ: John Wiley \& Sons.

Kessler, E. H., and Chakrabarti, A. K. (1996). Innovation speed: A conceptual model of context, antecedents, and outcomes. Academy of Management Review, 21(4), 1143-1191.

Khoshgoftar, M., \& Osman, O. (2009). Comparison of Maturity Models. New York: IEEE.

Killen, C. P., \& Kjaer, C. (2012). Understanding project interdependencies: The role of visual representation, culture and process. International Journal of Project Management, 30(5), 554-566. http://dx.doi.org/10.1016/ j.ijproman. 2012.01.018

Kowalska-Styczen, A., \& Sznajd-Weron, K. (2012). Access to information in word of mouth marketing within a cellular automata model. Advances in Complex Systems, 15(8), 17 http://dx.doi.org/10.1142/S0219525912500804

Lacher, R. C., Coats, P. K., Sharma, S. C., \& Fant, L. F. (1995). A Neural-Network for Classifying the Financial Health of a Firm. European Journal of Operational Research, 85(1), 53-65. http://dx.doi.org/10.1016/0377-2217(93)E0274-2

Landeta, J. (2006). Current validity of the Delphi method in social sciences. Technological Forecasting and Social Change, 73(5), 467-482. http://dx.doi.org/10.1016/j.techfore.2005.09.002

Langerak, F., Griffin, A., \& Hultink, E. J. (2010). Balancing Development Costs and Sales to Optimize the Development Time of Product Line Additions. Journal of Product Innovation Management, 27(3), $336-348$. http://dx.doi.org/10.1111/j.1540-5885.2010.00720.x

Lenfle, S., \& Loch, C. (2010). Lost Roots: How Project Management Came to Emphasize Control over Flexibility and Novelty. California Management Review, 53(1), 32-55. http://dx.doi.org/10.1525/cmr.2010.53.1.32

Levin, G. (2010). Interpersonal skills for Portfolio, Program, and Project Managers: Management Concepts.

McDonough, E. F. (2000). Investigation of factors contributing to the success of cross-functional teams. Journal of Product Innovation Management, 17(3), 221-235. http://dx.doi.org/10.1016/S0737-6782(00)00041-2

Mahadevan, B. (2000). Business models for Internet-based E-commerce: An anatomy. California Management Review, 42(4). http://dx.doi.org/10.2307/41166053 
Matsui, Y., Abdallah, A. B., Sato, O., \& Kitanaka, H. (2008). International Comparison of Manufacturing Practices and Performance.

Mian, A., Takala, J., \& Kekale, T. (2008). Role of Organizational Culture for Knowledge Sharing in Projects. 2008 Portland International Conference on Management of Engineering \& Technology, Vols 1-5, 962-968.

Morris, P. W. G. (1994). The Management of Projects. London: Thomas Telford. http://dx.doi.org/10.1680/mop.16934

Mullaly, M. E., \& Thomas, J. (2010). Re-thinking project management maturity. Paper presented at the PMI Research and Education Conference, Washington, D.C.

NAICS. (2012). North American Industry Classification System Washington, DC: U.S. Census Bureau.

Neverauskas, B., \& Stankevicius, V. (2008). Project Management: Research and Studies at the Faculty of Economics and Management of Kaunas University of Technology. Inzinerine Ekonomika-Engineering Economics(4), 59-66.

Omorede, A., Thorgren, S., \& Wincent, J. (2013). Obsessive passion, competence, and performance in a project management context. International Journal of Project Management, 31(6), 877-888. http://dx.doi.org/10. 1016/j.ijproman.2012.09.002

Onkal, D., Sayim, K. Z., \& Gonul, M. S. (2013). Scenarios as channels of forecast advice. Technological Forecasting and Social Change, 80(4), 772-788. http://dx.doi.org/10.1016/j.techfore.2012.08.015

Palacios-Marques, D., Cortes-Grao, R., \& Carral, C. L. (2013). Outstanding knowledge competences and web 2.0 practices for developing successful e-learning project management. International Journal of Project Management, 31(1), 14-21. http://dx.doi.org/10.1016/j.ijproman.2012.08.002

Pasian, B. L. (2011). Project management maturity: a critical analysis of existing and emergent contributing factors (pp. 266). Sydney: Faculty of Design, Architecture and Building, University of Technology.

Pemsel, S., \& Wiewiora, A. (2013). Project management office a knowledge broker in project-based organisations. International Journal of Project Management, 31(1), 31-42 http://dx.doi.org/10.1016/j.ijproman.2012.03.004

PMI. (2008). Organizational Project Management Maturity Model (OPM3®), Knowledge Foundation - 2nd Edition (pp. 204). Newtown Square, PA, USA: Project Management Institute.

Prasnikar, J., \& Skerlj, T. (2006). New product development process and time-to-market in the generic pharmaceutical industry. Industrial Marketing Management, 35(6), 690-702. http://dx.doi.org/10.1016/j.indmarman.2005.06.001

Radziszewska-Zielina, E. (2010). Analysis of the Impact of the Level of Partnering Relations on the Selected Indexes of Success of Polish Construction Enterprises. Inzinerine Ekonomika-Engineering Economics, 21(3), 324-335.

Rohrbeck, R. (2010). Towards A Maturity Model For Organizational Future Orientation. Academy of Management Proceedings, 2010(1), 1-6.

Rudzianskaite-Kvaraciejiene, R., Apanaviciene, R., \& Butauskas, A. (2010). Evaluation of Road Investment Project Effectiveness. Inzinerine Ekonomika-Engineering Economics, 21(4), 368-376.

Scapolo, F., \& Miles, I. (2006). Eliciting experts' knowledge: A comparison of two methods. Technological Forecasting and Social Change, 73(6), 679-704. http://dx.doi.org/10.1016/j.techfore.2006.03.001

Shenhar, A. J. (2001). One size does not fit all projects: Exploring classical contingency domains. Management Science, 47(3), 394-414. http://dx.doi.org/10.1287/mnsc.47.3.394.9772

Shenhar, A. J., \& Dvir, D. (1996). Toward a typological theory of project management. Research Policy, $25(4), 607-632$. http://dx.doi.org/10.1016/0048-7333(95)00877-2

Spalek, S. (2011). Managing projects in an industrial environment. An overview of the project management maturity models. Paper presented at the 16th Annual International Conference on Industrial Engineering Theory, Applications and Practice - IJIE, Stuttgart, Germany.

Spalek, S. (2013). Improving Industrial Engineering Performance through a Successful Project Management Office. Inzinerine Ekonomika-Engineering Economics, 24(2), 88-98.

Spalek, S. (2014). Does Investment in Project Management Pay Off? Industrial Management \& Data Systems, 114(5), 832-856. http://dx.doi.org/10.1108/IMDS-10-2013-0447

Tan, W. P., Sauser, B. J., \& Ramirez-Marquez, J. E. (2011). Analyzing Component Importance in Multifunction Multicapability Systems Developmental Maturity Assessment. IEEE Transactions on Engineering Management, 58(2), 275-294. http://dx.doi.org/10.1109/TEM.2010.2071877

Thomke, S., \& Reinertsen, D. (1998). Agile product development: Managing development flexibility in uncertain environments. California Management Review, 41(1). http://dx.doi.org/10.2307/41165973

Wilson, K., \& Wauson, J. (2010). The AMA handbook of business writing : the ultimate guide to style, grammar, usage, punctuation, construction, and formatting. New York: American Management Association.

Wright, R. N., Rosenfield, A. H., \& Fowell, A. J. (1995). Report on Federal Research in Support of the US Construction Industry. Washington, DC.: National Science and Technology Council.

Wyrozebski, P., \& Spalek, S. (2014). An Investigation of Planning Practices in Select Companies. Management and Production Engineering Review, 5(2), 78-87. http://dx.doi.org/10.2478/mper-2014-0020

Zavadskas, E. K., Turskis, Z., Ustinovichius, L., \& Shevchenko, G. (2010). Attributes Weights Determining Peculiarities in Multiple Attribute Decision Making Methods. Inzinerine Ekonomika-Engineering Economics, 21(1), $32-43$.

The article has been reviewed.

Received in October, 2014; accepted in December, 2014. 